\title{
BAHAYA NARKOBA DIKALANGAN REMAJA
}

\author{
Achmad Hasfa Jauhari \\ Prodi Kesehatan Masyarakat \\ IIK strada indonesia \\ Kresekjr276@gmail.com
}

\begin{abstract}
Abstrak
Tujuan penulisan ini adalah untuk menjelaskan bahaya narkoba dikalangan remaja, jumlah pengguna narkoba di Indonesia terus meningkat, sebagian besar penggunnya adalah para remaja. Dari masalah yang sudah banyak terjadi sekarang ini, banyak. Namun karena banyak penyalahgunaan narkoba jenis ini, akhirnya di dunia pengobatan tidak lagi digunakan. Jenis narkoba yang sering disalahgunakan dan menyebabkan ketergantungan. Penggunaan narkoba ada berbagai alasan diantaranya untuk mengatasi stress, untuk bersenang-senang, atau untuk bersosialisasi. Analisis data yang digunakan adalah dengan menganalisis berbagai informasi yang dikumpulkan dari dari media massa yang diperkuat dengan sumber yang ada dibuku menjabarkan apa itu bahaya narkoba, faktor penyebab narkoba di kalangan remaja, upaya mengatasi penggunaan narkoba, Hasil penulisan menunjukan bahwa : faktor yang menyebabkan para remaja menyalahgunakan narkoba di antara faktor keluarga yang kurang memperhatikan anaknya,dan juga faktor lingkungan juga dapat berpengaruh besar. Dengan pendidikan dan pendidikan agama adalah sebagai tembok paling luar mencegah penyalahgunaan narkoba.
\end{abstract}

Keywords : Bahaya Narkoba, Faktor penyebab, Upaya.penanggulangan. 


\section{Latar belakang}

Tahun 2013 narkoba masih menjadi masalah utama di negara indonesia. Narkoba selalu menghantui generasi muda yang sedang mencari jati diri. Hal ini sangat mengkhawatirkan, karena sasaran penyebaran narkoba yang paling mudah adalah para pelajar dan mahasiswa. Berdasarkan data dari Badan Narkotika Nasional (BNN), pengguna narkoba tahun 2013 sudah mencapai 3,8 juta. Jumlah ini meningkat dibanding tahun sebelumnya sebesar 3,6 juta. 22\% diantaranya, berasal dari kalangan pelajar dan mahasiswa. Narkoba jenis ganja,ekstasi maupun shabu-shabu menjadi favorit di kalangan ini (Rudi Qunsul,2013).

Jika hal ini terus menerus dibiarkan, maka tidak tidak menutup kemungkinan generasi muda akan hancur dan mudah terpengaruh oleh hal hal yang negatif. Menjadikan citra bangsa indonesia terpuruk dan rendah dimata dunia. Mengingat dampak narkoba yang bersifat merusak dan mematikan mental, jiwa, dan raga. Narkoba juga menghambat generasi muda untuk menjadi penerus bangsa yang berkualitas, karena sebagian besar para pelajar yang sedang menempuh pendidikan telah terpengaruhi oleh narkoba. Hal ini membuat para generasi muda menjadi malas dan hanya menginginkan narkoba sebagai kebutuhan yang harus diutamakan dan mengacuhkan kehidupan orang-orang yang berada disekelilingnya.

Berdasarkan latar belakang diatas pulis ingin mengetahui bahaya narkoba bagi kesehatan, faktor penyebab para remaja menggunakan narkoba, dan bagaimana upaya yang dilakukan untuk mengatasi penggunaan narkoba dikalangan remaja.

\section{Kasus/masalah}

Narkoba selalu menghantui generasi muda yang sedang mencari jati diri. Karena sasaran penyebaran narkoba yang paling mudah adalah para pelajar dan anak yang masih diusia labil dan mahasiswa. Mengingat dampak narkoba yang bersifat merusak dan mematikan mental, jiwa dan raga. Dan untuk tujuan orang tua harus menjaga dan memperhatikan anak-anaknya agar tidak terjerumus kedalam perilaku yang tidak pantas dicoba. Dan kita sebagai anak remaja harus bisa mengontrol agar tidak ikut-ikut mengkonsumsi narkoba tersebut kalau bisa kita memberitahu atau mengarahkan kepada anak-anak remaja lainya kalau mengkonsumsi narkoba tidak baik untuk tubuh dan kesehatan.

\section{Tinjauan pustaka}

A. Tinjauan Umum Tentang Narkoba

\section{Pengertian Narkoba}

Narkoba atau Napza adalah obat/bahan/zat yang bukan tergolong

makanan. Jika di minum, di hisap, di hirup, di telan atau di suntikkan, berpengaruh terutama pada kerja otak (susunan saraf pusat), dan seiring menyebabkan ketergantungan. Akibatnya kerja otak berubah (meningkat atau menurun). Demikian pula fungsi vital organ tubuh lain (jantung, peredaran darah, 
pernapasan, dan lain-lain). Narkoba yang di telan masuk ke lambung, kemudian ke pembuluh darah. Jika di hisap atau dihirup, zat diserap masuk kedalam pembuluh darah melalui saluran hidung dan paru-paru. Jika zat di suntikkan, langsung masuk ke aliran darah. Darah membawa zat itu ke otak. 8 Narkoba (narkotika, psikotroptrika, dan obat terlarang) adalah istilah penegak hukum dan masyarakat. Narkoba disebut berbahaya karena tidak aman digunakan manusia. Oleh karena itu, penggunaan, pembuatan, dan peredarannya di atur dalam undang-undang. Barang siapa menggunakan dan mengedarkannya di luar ketentuan hukum, di kenai sanksi pidana penjara hukuman dan denda. Napza (narkotika, psikotropika, zat adiktif lain) adalah istilah dalam dunia kedokteran. Penekanannya pada pengaruh ketergantungan. Oleh karena itu, selain narkotika dan psikotropika, yang termasuk Napza adalah juga obat, bahan atau zat yang tidak diatur dalam undang-undang, tetapi menimbulkan ketergantungan, dan sering disalahgunakan.

Narkoba yang di maksud disini adalah narkotika, psikotropika, dan zat adiktif lain. Digunakan istilah narkoba, karena telah menjadi bahasa umum di masyarakat. Akan tetapi, ruang lingkupnya meliputi Napza, sebab zat adiktif lain, seperti nikotin dan alkohol, sering menjadi pintu masuk pemakaian narkoba lain yang berbahaya. Juga Inhalansia dan Solven, yang terdapat pada berbagai keperluan rumah tangga, bengkel, kantor, dan pabrik yang sering disalahgunakan, terutama oleh anak-anak. Dahulu beberapa jenis narkoba alami, seperti Opium (getah tanaman candu), kokain dan ganja, di gunakan sebagai -. Akan tetapi, sekarang sering digunakan lagi dalam pengobatan karena berpotensi menyebabkan ketergantungannya yang tinggi.

Sebagian jenis narkoba dapat digunakan pada pengobatan, tetapi karena menimbulkan ketergantungan, penggunaannya sangat terbatas sehingga harus berhati-hati dan harus mengikuti petunjuk dokter atau aturan pakai. Contoh, Morfin (yang berasal dari opium mentah), Petidin (opioda sinetik), untuk menghilangkan rasa sakit pada penyakit kanker, Amfetamin untuk mengurangi nafsu makan, serta berbagai jens pil tidur dan obat penenang. Kodein, yang merupakan bahan alami yang terdapat pada candu, secara luas digunakan pada pengobatan sebagai obat batuk. 
Obat adalah bahan atau zat, baik sinetis, semi sinetis atau alami, yang aturan pakai, jika makanan atau minuman, yang berbahaya bagi manusia. Contoh

racun adalah obat anti serangga atau hama.berkhasiat untuk menyembuhkan, akan tetapi penggunaannya harus mengikuti

\section{Pembahasan}

\section{A. Narkoba}

Narkoba terbuat dari tanaman atau bukan tanaman dan dapat juga terbuat dari bahan sintetis maupun semi sintetis yang mengakibatkan kehilangan kesadaran diri. Narkoba adalah zat atau obat yang dapat merusak sistem kerja saraf manusia, jika mengkonsumsinya secara terus menerus.

Hal ini diperkuat oleh pernyataan Lydia $(2006 ; 5)$ menyatakan bahwa narkoba atau napza adalah obat/bahan/zat, yang bukan tergolong makanan. Jika diminum, diisap, dihirup, ditelan atau disuntikkan, berpengaruh terutama pada kerja otak (susunan saraf pusat), dan sering menyebabkan ketergantungan. Akibatnya, kerja otak berubah (meningkat atau menurun). Demikian pula fungsi vital organ tubuh lain. (jantung, peredaran darah, pernapasan, dan lain-lain).

Selain itu, Rachman $(1986 ; 10)$ berpendapat bahwa narkotika adalah zat yang jika dimakan atau dimasukkan (disuntikan) ke dalam tubuh manusia, dapat mengubah satu atau lebih fungsi badan manusia.

Berdasarkan pendapat diatas dapat disimpulakan bahwa narkoba bukanlah golongan makanan, dan apabila diminum, diisap, dihirup, ditelan atau disuntikkan kedalam tubuh akan menimbulkan perubahan kerja otak tidak stabil. Dan jika telah ketergantungan, akan merusak fungsi vital organ tubuh lainnya.

\section{B. Bahaya Narkoba}

Narkoba memiliki banyak dampak negatif bagi para penggunannya dan masyarakat disekitarnya. Dampak dari penggunaan narkoba yang berlebihan akan menimbulkan halusinasi, akan merasakan bahagia yang berlebihan, depresi, dan jika mengkonsumsinya secara ketergantungan akan merusak semua organ dalam tubuh dan fungsi syaraf menurun. Jika pengguna narkoba yang sudah ketergantungan atau sedang sakaw dan tidak mendapatkan narkoba, maka pengguna tersebut akan merasakan sakit yang menyiksa tubuhnya.

Hal ini diperkuat oleh pernyataan Jael Muhamad (2013) yang mengatakan tentang bahaya penyalahgunaan narkoba bagi tubuh manusia.

Secara umum semua jenis narkoba jika disalahgunakan akan memberikan empat dampak sebagai berikut:

Depresan adalah pemakai akan tertidur atau tidak sadarkan diri. Halusinogen adalah pemakai akan berhalusinasi (melihat sesuatu yang sebenarnya tidak ada). Stimulan adalah mempercepat kerja organ tubuh seperti jantung dan otak sehingga pemakai merasa lebih bertenaga untuk sementara waktu. Karena organ tubuh terus dipaksa bekerja di luar batas normal, lama-lama saraf-sarafnya akan rusak dan bisa mengakibatkan kematian. 
Adiktif adalah pemakai akan merasa ketagihan sehingga akan melakukan berbagai cara agar terus bisa mengonsumsinya. Jika pemakai tidak bisa mendapatkannya, tubuhnya akan ada pada kondisi kritis (sakaw).

\section{Faktor penyebab narkoba di kalangan remaja}

Pada umumnya masa para remaja adalah mencari jati diri, saat mencari jati diri inilah terjadi individu ingin bersosoialisasi dengan individu yang lain. Remaja ini akan mudah mencari pergaulan. Inilah hal-hal yang sangat dikhawatirkan oleh orang tua. Karena para remaja belum mempunyai pikiran yang matang dan belum bisa berpikir panjang, jadinya para remaja mencari teman bergaul tanpa melihat baik buruknya teman yang diajak bergaul. Bila dia mendapatkan teman yang memiliki latar belakang keluarga yang salah dan kebetulan teman gaulnya adalah pecandu narkoba, tidak menutup kemungkinan anak yang polos tadi akan terkena bujuk rayu oleh teman bergaulnya untuk menggunakan narkoba bersama-sama. Danalasan lain para remaja menggunakan narkoba adalah alasan diantaranya untuk mengatasi stress, untuk bersenang-senang, atau untuk bersosialisasi.

Hal ini diperkuat oleh pernyataan Abdul Rauf (2012) yang menjelaskan tentang faktor yang menyebabkan remaja melakukan penyalahgunaan narkoba adalah sebagai berikut:

Ajakan, bujukan dan iming-iming teman atau anggota kelompok sebaya. Cenderung memiliki gangguan jiwa seperti kecemasan, obsesi (memikirkan sesuatu secara berulang-ulang), apatis, menarik diri dalam pergaulan, depresi, kurang mampu menghadapi stres, atau hiperaktif.

Suka berpetualang, mencari sensasi, melakukan hal-hal yang mengandung resiko bahaya yang berlebihan. Ketidak tahuan akan bahaya narkoba atau tidak memikirkan akan bahaya narkoba. Orang tua tidak acuh dan tidak mengadakan pengawasan terhadap anaknya. Tidak ada perhatian, kehangatan, kasih sayang dalam keluarga.

\section{D.Upaya mengatasi penggunaan narkoba}

Upaya untuk mengatasi penggunaan narkoba pada remaja adalah dengan cara melakukan tindakan preventif, seperti memberikan pendidikan agama sejak usia dini, agar ketika tumbuh dewasa bisa memikirkan setiap tindakan yang akan dilakukan dengan benar dan tidak berjalan di jalan yang sesat. Menjalin hubungan yang harmonis antara orang tua dan anak. Orang tua juga harus memberikan contoh yang baik kepada anaknya. Memberikan pengetahuan terhadap anak usia dini tentang jenis-jenis narkotika, dan dampak negatif yang ditimbulkan akibat penyalahgunaan narkotika.

Melakukan tindakan hukum, tindakan hukum sangat penting karena tindakan hukum bisa memberikan efek jera terhadap konsumen, pengedar, bandar, dan tokoh yang membantu melancarkan bisnis narkotika. Penyebaran narkotika bisa dilakukan dengan cara bekerjasama antara mayarakat, LSM, Polisi, dan insatansi penegak hukum dalam hal pengawasan penggunaan narkotika di lingkungan sekitar.

Merahabilitasi, Rehabilitasi adalah tempat dimana para pecandu diberikan pengobatan. Biasanya rehabilitasi terdapat di rumah sakit yang menyediakan ruangan untuk para pasien pecandu 
narkoba. Sekarang sudah banyak pondok pesantren yang membuka pengobatan bagi pecandu narkoba, pondok pesantren mengobati para pecandu dengan memberikan pencerahan jiwa melalui ceramah-ceramah keagamaan, tidak hanya itu saja, di pondok pesantren juga mengingatkan siapakah kita yang sebenarnya, dan untuk apa kita hidup di dunia ini.

Hal ini diperkuat oleh pendapat dari Dimaslova's (2012) dengan cara meningkatkan iman dan taqwa melalui pendidikan agama dan keagamaan baik di sekolah maupun di masyarakat.Bukan hanya itu, bahkan anak yang masih dalam kandungan Sang Ibupun usaha mendidik anak tersebut sudah harus dilaksanakan yaitu dengan jalan kedua orangtuanya selalu berakhlak dan berbudi baik, menyempurnakan ibadah, memperbanyak bersedekah, membaca Al Qur'an, berpuasa, dan berdoa kepada Allah dengan tulus agar anak yang akan lahir nanti dalam bentuk fisik yang sempurna dan merupakan anak yang berjiwa shaleh.

Meningkatkan peran keluarga melalui perwujudan keluarga sakinah, sebab peran keluarga sangat besar terhadap pembinaan diri seseorang. Hasil penelitia menunjukkan bahwa anak-anak nakal dan brandal pada umumnya adalah berasal dari keluarga yang berantakan (broken home). Dan unit terkecil dari masyarakat adalah rumah tangga. Di sinilah tempat pertama bagi anak-anak memperoleh pendidikan perihal nilai-nilai sejak anak dilahirkan. Maka dengan demikian orang tua sangat berperan pertama kali dalam mendidik, mengajar, membimbing, membina, dan membentuk anak-anaknya dengan.

\section{Kesimpulan}

Dari pembahasan yang telah diungkapakan, dapat disimpulkan bahwa narkoba sangat mudah menyerang di kalangan remaja dan siapa saja. Narkoba dapat merusak mental dan kesehatan fisik para pengunannya. Narkoba dapat merusak system saraf dan beberapa organ tubuh kita. Orang yang sudah merasakan kenikmatan menggunakan narkoba akan terus menggunakan narkoba karena itu akan membuat pengguna merasa kecanduan. Mereka akan menggunakan berbagai cara untuk bisa mendapatkan narkoba bahkan samapi ada yang mencuri. Sudah banyak korban dari penggunaan narkoba bahkan sampai harus kehilangan nyawanya.

Di Indonesia narkoba bisa menyebar luas secara mudah, karena kurangnya pengawasan yang diberikan oleh semua masyarakat, baik orang tua maupun pihak-pihak yang berwajib. Para remaja mudah tergoda menggunakan narkoba karena pergaulan yang disekitarnya, tanpa mengetahui latar belakang teman pergaulanya. Para pengguna narkoba mempunyai semboyan " jika saya hitam, kamu juga harus hitam" , yang artinya para pengguna narkoba yang telah frustasi mengajak teman-temanya untuk mengonsumsi narkoba bersama-sama. Seperti itulah penyebaran pengguna narkotika berkembang biak secara mudah dikalangan para remaja.

Agar anak tidak salah pergaulan, maka orang tua juga harus bisa menjadi teman dan memberikan pengarahan dan pengawasan yang baik dan tidak mengikat. Lingkungan sekolah juga harus berperan aktif untuk mengawasi muird nya dari jeratan narkoba. Selain itu, lingkungan social, lingkungan di sekitar kita harus bisa memberikan dampak positif memberikan kegiatan-kegiatan remaja yang bermanfaat. Jadi, sebagai penerus bangsa yang baik dan bertanggung jawab, mari kita bersama-sama mengawasi penyebaran narkoba di kalangan remaja agar tidak menyebar luas. Dan menyelamatkan generasi muda dari ancaman bahaya narkoba, untuk mencapai suatu bangsa yang maju, seperti harapan para pejuang yang telah mengorbankan hidupnya untuk bangsa kita. Mulailah 
dari hal yang kecil yaitu diri kita sendiri, tanamkan pada diri kita untuk selalu hidup sehat, berfikiran positif dan selalu mendekatkan diri pada Tuhan Yang Maha Esa.

\section{Daftar pustaka}

Martono,Lydia Herlina, dan Joewana, Setya. 2006. Pencegahan dan Penanggulangan Penyalahgunaan Narkoba Berbasis Sekolah. Jakarta: Balai Pustaka.

Hermawan.S, Rachman. 1986. Penyalahgunaan Nakotika Oleh Para Remaja. Bandung: Eresco Bandung. 